\title{
New combinations in Decalobanthus (Convolvulaceae)
}

\author{
Ana Rita G. Simões ${ }^{1,2,3}$, Ponprom Pisuttimarn ${ }^{4}$, Pimwadee Pornpongrungrueng ${ }^{4} \&$ Lars W. Chatrou ${ }^{3}$
}

Summary. The recent revisionary work of "Merremieae" has resulted in the segregation of the c. 100 species of the pantropical genus Merremia into six genera. Thus, the formerly monotypic genus Decalobanthus was expanded, aggregating 13 species of Merremia s.l. The genus delimitation is coherent, with strong molecular phylogenetic and morphological support. Decalobanthus, hence, consists of woody climbers with broadly cordate leaves, large yellow or white flowers, four-valved chartaceous capsules, and is mostly distributed in Asia and the Pacific. Four species have remained classified in Merremia s.l., although molecular and morphological evidence unequivocally suggests their placement in Decalobanthus. In the present work, these are formally transferred to the genus, which now extends to 17 species.

Key Words. liana, Merremia, Merremieae, morning-glories, woody climbers.

\section{Introduction}

Recent taxonomic rearrangements in tribe Merremieae (Convolvulaceae) have resulted in the dissolution of the pantropical genus Merremia sensu lato into six genera: Merremia Hallier f. (sensu stricto), Decalobanthus Ooststr., Camonea Raf., Distimake Raf., Xenostegia D.F.Austin \& Staples and Operculina Silva Manso (Simões et al. 2015; Simões \& Staples 2017). A considerable number of species are still placed in Merremia s.l. (Simões \& Staples 2017), awaiting further phylogenetic, morphological and palynological studies to ascertain their generic placement.

Decalobanthus, in particular, results from the expansion of a previously monotypic genus endemic to Sumatra (Indonesia), with the type species D. sumatranus Ooststr. This genus was initially described by Van Ooststroom (1936) for the presence of a small tubular corolla, the lobes of which are reflexed, with each lobe further parted into two. As the flowers of Convolvulaceae are pentamerous, this creates a particular "10-lobed" arrangement of the corolla fauce, that inspired the generic name Decalobanthus. As morphological and molecular studies recently brought to light that this species is nested within a clade of other woody climbers from SE Asia (Simões et al. 2015; Simões \& Staples 2017), the generic delimitation was expanded, accommodating 12 additional species previously placed in Merremia s.l. The genus now comprises 13 species, the monophyly of which is strongly supported in molecular phylogenetic analyses based on ITS and three plastid markers (Simões et al. 2015; Fig. 1).

Decalobanthus is not characterised by unequivocal synapomorphies, viz. characters that uniquely evolved in this genus. However, species of Decalobanthus are robust woody climbers or lianas, for which they are very easily separated from the herbaceous or slender twining herbs of Merremia s.s. (Fig. 2). A combination of other morphological characters helps to differentiate them from closely related genera: leaves simple, entire, commonly large and broadly cordate; inflorescences paniculate or corymbiform, the lowermost bract often foliaceous; sepals strongly convex (boat-shaped); corolla bright yellow to white, usually glabrous outside; anthers spirally twisting at dehiscence; fruits valvate capsules with the exocarp delaminating above the middle (lower half is dark brown, upper half is strawcoloured); seeds always pubescent, often with long golden hairs either covering the entire surface or concentrated along the edges of the seeds (Simões \& Staples 2017; Fig. 2). The genus is distributed mostly across SE Asia and the Pacific (Map 1), with one species being widespread to Eastern Africa and Madagascar (D. peltatus (L.) A.R.Simões \& Staples) and Santa Cruz Island of North America (D. bracteatus (P.S.Bacon) A.R.Simões \& Staples) (Map 1).

\footnotetext{
Accepted for publication 8 July 2020. Published online 14 December 2020

1 Royal Botanic Gardens Kew, Richmond, Surrey, TW9 3AE, UK. e-mail: a.simoes@kew.org

2 Singapore Herbarium, Singapore Botanic Gardens 1 Cluny Road, Singapore 259569, Singapore.

3 Systematic and Evolutionary Botany lab, Ghent University K.L. Ledeganckstraat 35, 9000 Ghent, Belgium.

4 Applied Taxonomic Research Center, Department of Biology, Faculty of Science, Khon Kaen University, Khon Kaen 40002, Thailand.
} 


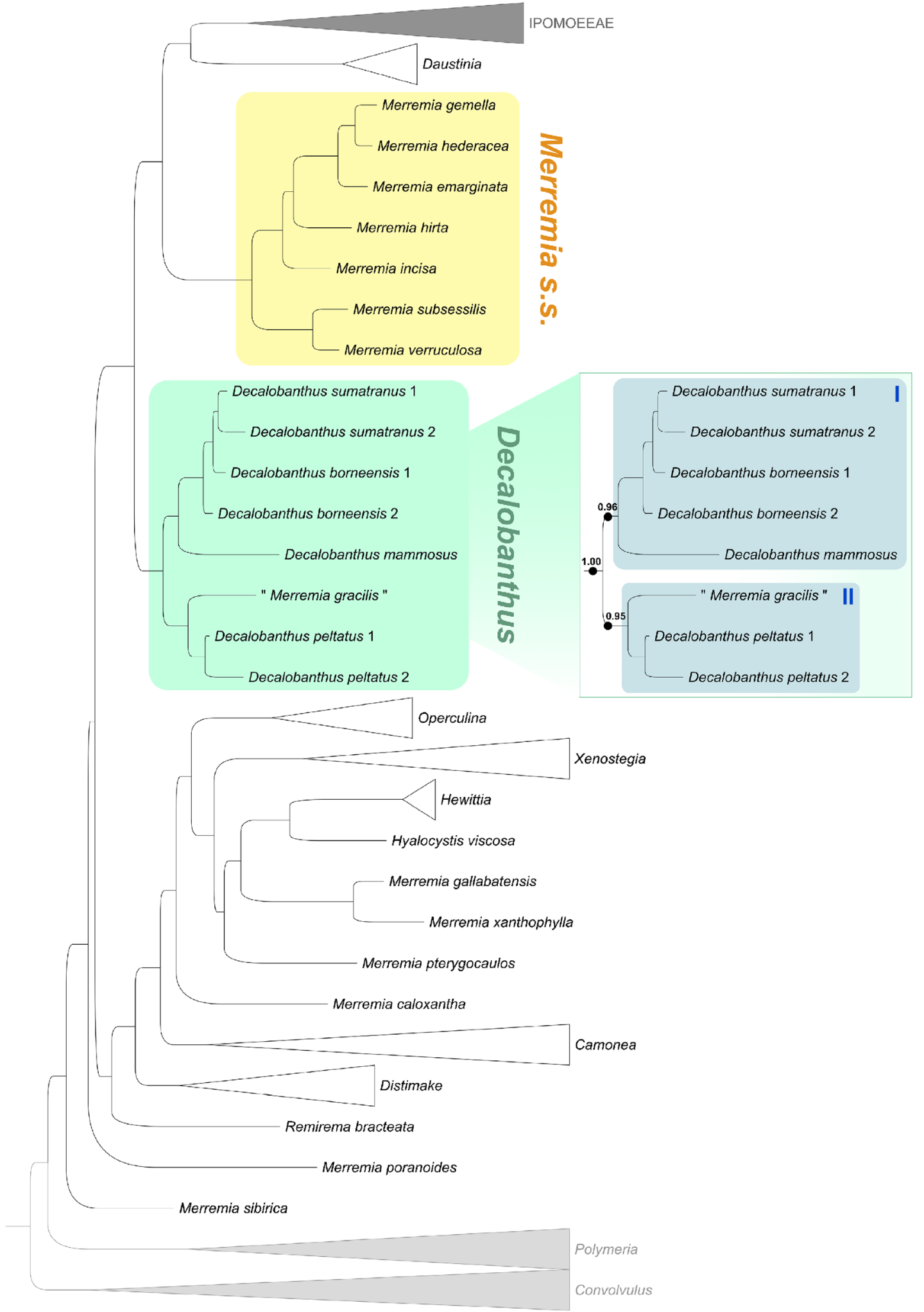

Fig. 1. Phylogenetic tree of the relationships in the former tribe Merremieae, adapted from Simões et al. (2015), showing the position of Decalobanthus and Merremia s.S., following the newly generic circumscriptions for the group (Simões \& Staples 2017). Decalobanthus and Merremia s.s. are resolved, along with Daustinia, as sister to tribe Ipomoeeae, while the remaining species of former Merremia s.l. and other allied genera, are resolved in a separate clade. The relationships between the genera have low support and are still mostly unresolved, although the clade of Decalobanthus is maximally supported ( $P P=1.00$ ) Two clades within the genus are also well supported (Clade I: PP = 0.96; Clade II: PP = 0.95), albeit with limited taxonomic sampling (Simões et al. 2015). 
Table 1. List of currently accepted species of Decalobanthus Ooststr. (sensu Simões \& Staples 2017), the four species here combined under Decalobanthus are included.

\begin{tabular}{|c|c|}
\hline Decalobanthus Ooststr. (sensu Simões \& Staples 2017) & Distribution \\
\hline Decalobanthus bimbim (Gagnep.) A.R.Simões \& Staples & China (Yunnan) to Vietnam \\
\hline Decalobanthus boisianus (Gagnep.) A.R.Simões \& Staples & S China to Indo-China, Indonesia (Sumatra) \\
\hline var. boisianus & S China to N Vietnam \\
\hline var. fulvopilosus (Gagnep.) A.R.Simões \& Staples & S China to N Vietnam \\
\hline var. sumatranus (Ooststr.) A.R.Simões \& Staples & Indonesia (Sumatra) \\
\hline Decalobanthus borneensis (Merr.) A.R.Simões \& Staples & Peninsular Malaysia, Indonesia (Borneo) \\
\hline Decalobanthus bracteatus (P.S.Bacon) A.R.Simões \& Staples & Solomon to N America (Santa Cruz) \\
\hline Decalobanthus calyculatus (Ooststr.) A.R.Simões \& Chatrou comb. nov. & Fiji (Taveuni) \\
\hline Decalobanthus clemensianus (Ooststr.) A.R.Simões \& Chatrou comb. nov. & Indonesia (Borneo-Sarawak) \\
\hline Decalobanthus crassinervius (Ooststr.) A.R.Simões \& Chatrou comb. nov. & Indonesia (Borneo) \\
\hline Decalobanthus gracilis (E.J.F.Campb. \& Argent) A.R.Simões \& Chatrou comb. nov. & Indonesia (Borneo-Sabah, Kalimantan) \\
\hline Decalobanthus eberhardtii (Gagnep.) A.R.Simões \& Staples & C Vietnam \\
\hline Decalobanthus elmeri (Merr.) A.R.Simões \& Staples & Indonesia (Borneo) \\
\hline var. elmeri & Indonesia (Borneo) \\
\hline var. glaberrimus (Ooststr.) A.R.Simões \& Staples & Indonesia (Borneo) \\
\hline Decalobanthus korthalsianus (Ooststr.) A.R.Simões \& Staples & Indonesia (Borneo) \\
\hline Decalobanthus mammosus (Lour.) A.R.Simões \& Staples & E India to Indo-China \\
\hline Decalobanthus pacificus (Ooststr.) A.R.Simões \& Staples & New Guinea to W Pacific \\
\hline Decalobanthus peltatus (L.) A.R.Simões \& Staples & Tanzania, W Indian Ocean, Trop. Asia to Pacific \\
\hline Decalobanthus pulcher (Ooststr.) A.R.Simões \& Staples & Indonesia (Borneo) \\
\hline Decalobanthus similis (Elmer) A.R.Simões \& Staples & Philippines \\
\hline Decalobanthus sumatranus Ooststr. & Indonesia (Sumatra, Borneo) \\
\hline
\end{tabular}

As a new expanded circumscription of Decalobanthus is adopted and contributes to a better understanding of the relationships and biogeographical patterns of this group of species, several challenges come in the way of a full revisionary study of this genus. Unlike many Convolvulaceae taxa, Decalobanthus are woody vines that grow in primary forests and require targeted fieldwork in undisturbed and well-conserved patches of forest. Many collections are available in Asian and European herbaria. Still, a significant proportion of the specimens is relatively old, preserved in alcohol, or have been treated with pest-control chemicals, which has impeded adequate molecular sampling of the genus. Also, the wide geographic range, with several narrow endemic species from hardly accessible areas, as the islands in the Pacific, further complicates the mission of sampling and morphologically comparing the taxa. Taxonomic studies are underway with the aim of improving our knowledge of the genus, namely by Pisuttimarn, who has conducted targeted fieldwork for specimen collection, and fresh samples for DNA analysis. However, it could be some time until we have the deep knowledge of the full morphological characterisation of the genus, a good understanding of the interspecific relationships, and a finer-tuned delimitation of the species.

The current expanded delimitation of Decalobanthus encompasses in the most part the species of Merremia previously placed in two sections: 1) section Hailale Hallier f., emended by Van Ooststroom (1939) (Merremia borneensis Merr., M. boisiana (Gagnep.) Ooststr., M. clemensiana Ooststr., M. crassinervia Ooststr., M. elmeri Merr., M. korthalsiana Ooststr., M. mammosa (Lour.) Hallier f., M. peltata (L.) Merr. and M. pulchra Ooststr.); and 2) section Wavula Ooststr. (which included M. similis Elmer, M. calyculata Ooststr. and M. pacifica Ooststr.) (Van Ooststroom 1939; Van Ooststroom \& Hoogland 1953). A few additional species were described or transferred into Merremia afterwards ( $M$. bracteata P.S.Bacon, M. gracilis E.J.F.Campb. \& Argent, M. eberhardtii (Gagnep.) T.N.Nguyen and M. bimbim (Gagnep.) Ooststr.).

In the light of molecular phylogenetic results (Simões et al. 2015; Fig. 1), and considering that these species present the diagnostic characters of Decalobanthus as expanded by Simões \& Staples (2017; Fig. 2), they have, for the most part, been combined under this name (Simões \& Staples 2017). However, two species in section Hailale (Merremia clemensiana Ooststr. and M. crassinervia Ooststr.), one in section Wavula (Merremia calyculata Ooststr.) and one without an assigned section (M. gracilis E.J.F.Campb. \& Argent) have not been, up until now, formally transferred to Decalobanthus, although they confidently belong in this genus. Merremia gracilis was even included in the molecular phylogenetic studies of Simões et al. (2015), and resolved as a member of the Decalobanthus clade. However, these names were never combined under Decalobanthus in Simões \& Staples (2017), for uncertainty about the species delimitation.

Three of the species (Merremia clemensiana, M. crassinervia and $M$. gracilis) are morphologically similar to Decalobanthus korthalsianus (Ooststr.) A.R.Simões \& Staples and overlap in geographical distribution (all documented as endemic to Borneo). Merremia calyculata is known only from the type specimen, collected on the Fiji Island of Taveuni (Smith 1991). The morphological and distributional overlap with D. pacificus (Ooststr.) 


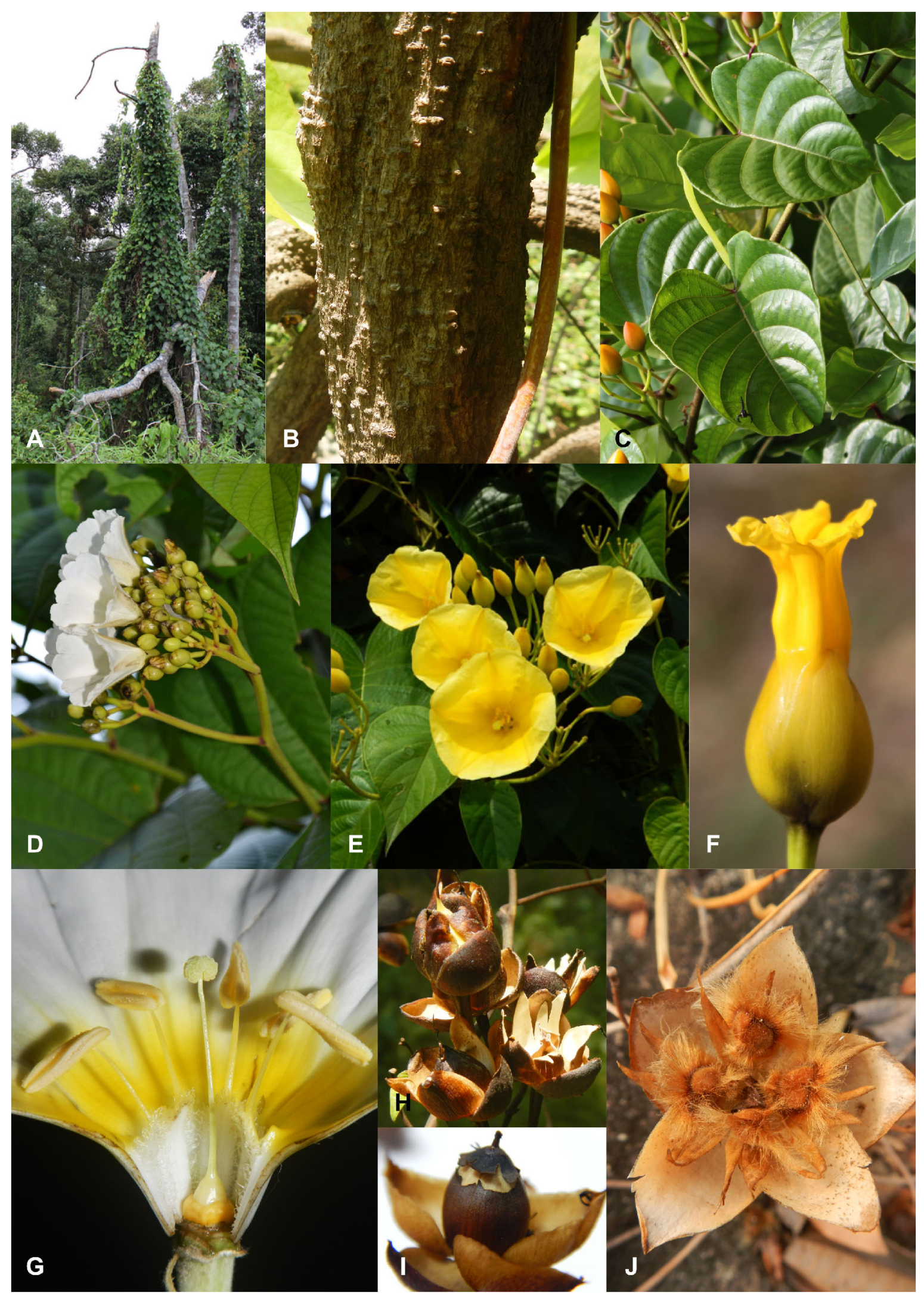


Fig. 2. Diagnostic morphological characters of Decalobanthus. A climbing habit, D. sumatranus, Indonesia, Sumatra (Staples 2532 [BM]); B woody stem, D. eberhardtii in cultivation at Suan Luang Rama IX Park, Bangkok, Thailand (Pisuttimarn 396 $[K K U]) ; C$ entire, cordate leaves, D. sumatranus, Indonesia, Sumatra (Staples 2532 [BM]); D-E inflorescence with campanulate white and bright yellow flowers, D. boisianus var. sumatranus, Vietnam (not collected); F tubular bright yellow flower, D. sumatranus, Indonesia, Sumatra (Staples 2532 [BM]); G detail of the inside of the corolla tube, showing twisted anthers and biglobose stigmas, D. eberhardtii in cultivation at Suan Luang Rama IX Park, Bangkok, Thailand (Pisuttimarn 396 [KKU]); $\mathrm{H}-\mathrm{I}$ fruit: $\mathrm{H}$ capsule dehiscing by 4 valves, each valve further splitting, D. peltatus, Phang Nga, Thailand (Pisuttimarn 251 [KKU]); I darker outside layer of the exocarp shedding and exposing the lighter layer below, D. bimbim in cultivation at Xishuangbanna Tropical Botanical Garden (not collected); J seeds with long golden hairs along the edges, D. mammosus, Ubon Ratchathani, Thailand (Pisuttimarn 246 [KKU]). PHOTOS: C, F A. R. SIMÕES; B, G, H, K P. PISUTTIMARN; D, E JANA LEONG; J SVEN LANDREIN.

A.R.Simões \& Staples is considerable, for which its status as a distinct species is also dubious and should deserve attention in future studies (Staples 2009, 2010).

In the context of this study, we propose to combine the names of these four species under Decalobanthus, given the confidence in their generic placement, to avoid ambiguity in systematic and floristic studies of the region.

Hence, in total, 17 taxa are now considered to belong in Decalobanthus, based on genetic markers and conspicuous morphology (Table 1). It is hoped that ongoing systematic, morphological, palynological and anatomical studies will contribute to further elucidation of the relationships between these species and the remainder of the genus.

\section{New combinations}

1. Decalobanthus calyculatus (Ooststr.) A.R.Simões $\mathcal{E}^{\circ}$ Chatrou, comb. nov.

http:/ /www.ipni.org/urn:lsid:ipni.org:names:77213102-1

Merremia calyculata Ooststr., Blumea 3: 265 (Van Ooststroom 1939). Type: Fiji, Taveuni, June 1860, Seemann 324 (holotype K [K000830927]; isotypes BM [BM000884662], GH [GH00054678])

\section{Decalobanthus clemensianus (Ooststr.) A.R.Simões $\mathcal{E}$ Chatrou, comb. nov.}

http://www.ipni.org/urn:lsid:ipni.org:names:77213103-1

Merremia clemensiana Ooststr., Blumea 3: 350 (Van Ooststroom 1939). Type: "Borneo. Sarawak, Kapit, upper Rejang R., 1929, J. Eं M. S. Clemens 21133 (holotype BO [BO177795]; isotypes A [A00054674] B [B_10_0241997, B_10_0241997], BISH [BISH1001147], BM [BM000797179], K [K000830845], L [L0004223, L0640533], MO [MO-694686], NY [NY00336580, NY00336581], P [P00622203]).

\section{Decalobanthus crassinervius (Ooststr.) A.R.Simões $\mathcal{E}$ Chatrou, comb. nov.}

http:/ /www.ipni.org/urn:lsid:ipni.org:names:77213104-1

Merremia crassinervia Ooststr., Blumea 3: 350 (Van Ooststroom 1939). Type: "Borneo. Sarawak, Saribas, Paku, 6 Dec. 1893," Haviland E Hose 3523E (holotype L [L0004224]; isotype K [K000830846], SAR [Hav. 3523A]).

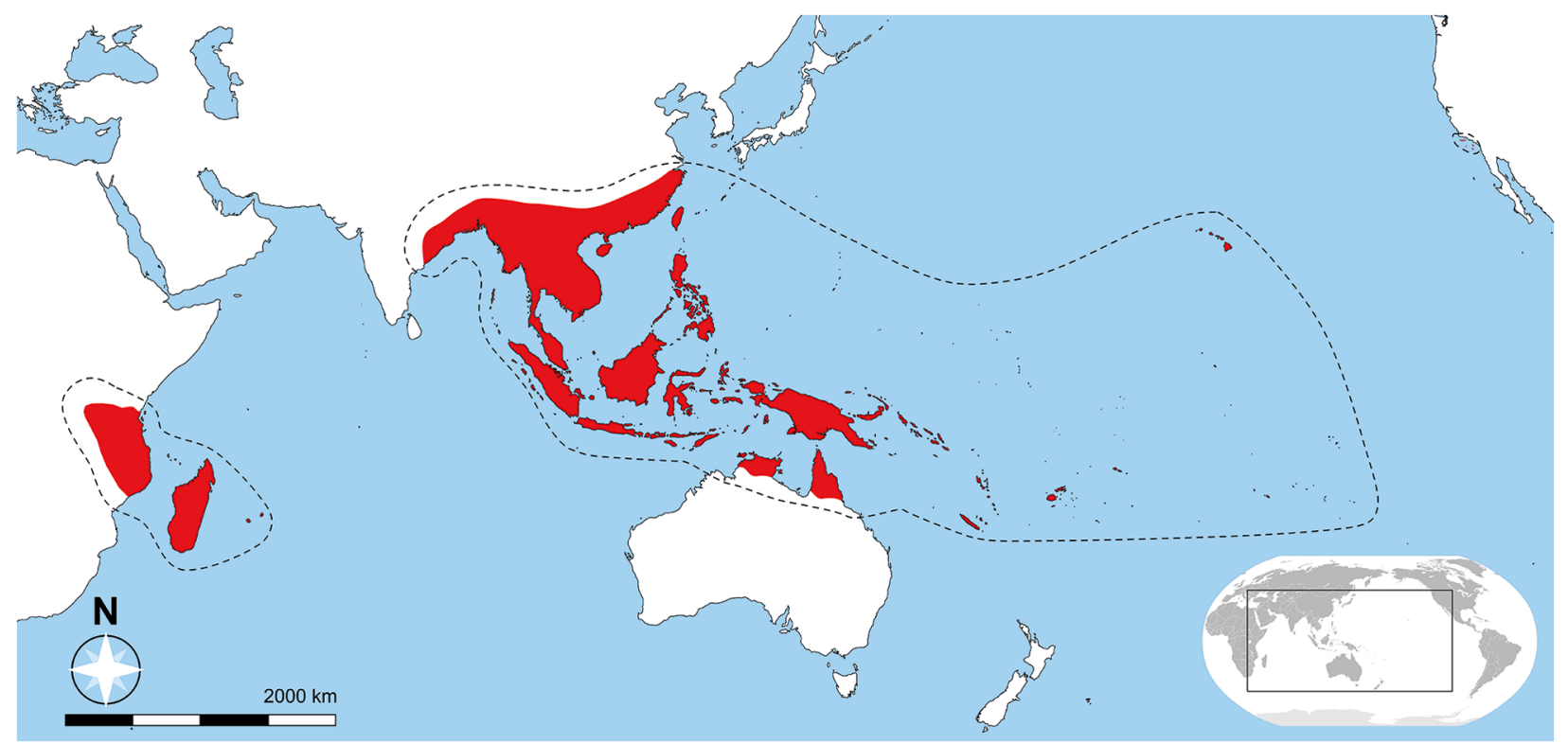

Map 1. Broad view of the distribution of the species of Decalobanthus. 
4. Decalobanthus gracilis (E.J.F.Campb. Eं Argent) A.R.Simões Ë Chatrou, comb. nov.

http:/ /www.ipni.org/urn:lsid:ipni.org:names:77213105-1

Merremia gracilis E.J.F.Campb. \& Argent, Notes Roy. Bot. Gard. Edinburgh 45: 345 (Campbell \& Argent 1988). Type: Malaysia. Sabah: Lahad Datu Distr., Ulu Segama, Danum Valley Field Centre, roadside, 4 Nov. 1985, Argent E Campbell 411854 (holotype SAN!; isotypes A [A00054677], BM [BM000797174], E [E00273914]).

\section{Acknowledgements}

Ana Rita G. Simões would like to thank all staff at Singapore Botanic Gardens, particularly the herbarium SING, the Humphrey Morrison Burkill Fellowship for funding a short research project on taxonomy of Decalobanthus (2013). In addition, Sven Landrein (Xishuangbanna Tropical Botanical Garden) and Jana Leong-Škorničková (Singapore Botanic Gardens) for the photographs, and Dr George Staples for the knowledge shared through the years, and the insightful discussions that involved the taxonomy and systematics of "Merremieae", in particular this genus, Decalobanthus. Ponprom Pisuttimarn thanks the Science Achievement Scholarship of Thailand (SAST), and Study and Research in Abroad Scholarship Fiscal Year of 2018, Graduated School, Khon Kaen University (Thailand).

Open Access This article is licensed under a Creative Commons Attribution 4.0 International License, which permits use, sharing, adaptation, distribution and reproduction in any medium or format, as long as you give appropriate credit to the original author(s) and the source, provide a link to the Creative Commons licence, and indicate if changes were made. The images or other third party material in this article are included in the article's Creative Commons licence, unless indicated otherwise in a credit line to the material. If material is not included in the article's
Creative Commons licence and your intended use is not permitted by statutory regulation or exceeds the permitted use, you will need to obtain permission directly from the copyright holder. To view a copy of this licence, visit http://creativecommons.org/ licenses/by/4.0/.

\section{References}

Campbell, E. J. F. \& Argent, G. C. G. (1988). New Merremia from Sabah. Notes Roy. Bot. Gard. Edinburgh 45: 345.

Simões, A.R., Culham, A. \& Carine, M. (2015). Resolving the unresolved tribe: a molecular phylogenetic framework for the Merremieae (Convolvulaceae). Bot. J. Linn. Soc. 179: $374-$ 387.

\& Staples, G. (2017). Dissolution of Convolvulaceae tribe Merremieae and a new classification of the constituent genera. Bot. J. Linn. Soc 183: 561 - 586.

Smith, A.C. (1991). Flora Vitiensis nova: a new Flora of Fiji (spermatophytes only) 5: 1 - 626. Pacific Tropical Botanical Garden, Lawaii, Hawaii.

Staples, G.W. (2009). Merremia pacifica (Convolvulaceae) recharacterised, with notes on other Pacific species. Kew Bull. 64: 333 - 338.

(2010). A checklist of Merremia (Convolvulaceae) in Australasia and the Pacific. Gard. Bull. Singapore 61: 483 - 522.

Van Ooststroom, S. J. (1936). On Decalobanthus, a new genus of Convolvulaceae from Sumatra. Blumea 2: 99 - 100.

(1939). The Convolvulaceae of Malaysia II. Blumea 3: 276 - 366.

\& Hoogland, R. D. (1953). Convolvulaceae. In: C. G. G. J. Van Steenis (ed.), Flora Malesiana ser. I, vol. 4, part 4: 388 - 512. Noordhoff-Kolff N.V., Jakarta, Indonesia.

\section{Publisher's Note}

Springer Nature remains neutral with regard to jurisdictional claims in published maps and institutional affiliations. 